\title{
Wpływ rodzaju napędu laboratoryjnego przesiewacza o drganiach prostoliniowych na parametry jego pracy w stanie ustalonym
}

\author{
Paweł Tomach (D), Jacek Feliks (D) \\ AGH Akademia Górniczo-Hutnicza, Wydział Inżynierii Mechanicznej i Robotyki, Kraków
}

\begin{abstract}
Streszczenie: W pracy przedstawiono wyniki badań ruchu drgającego laboratoryjnego przesiewacza o prostoliniowej (odcinkowej) trajektorii drgań. Badania miały na celu wskazanie różnic wynikających z zastosowanego wariantu układu wymuszenia drgań przesiewacza. Wariantami tymi były: układ klasyczny (dwa silniki asynchroniczne napędzające za pomocą sprzęgieł oponowych wibratory bezwładnościowe) oraz układ dwóch silników wibracyjnych stosowanych w nowszych rozwiązaniach przesiewaczy przemysłowych - mocowanych bezpośrednio do rzeszota. Badania, polegające na pomiarze amplitud drgań i ich trajektorii w wytypowanych punktach pomiarowych umieszczonych na rzeszocie przesiewacza, przeprowadzono dla trzech różnych częstotliwości drgań - takich samych dla różnych układów napędowych. Otrzymane wyniki badań potwierdziły celowość modernizacji starszych konstrukcji przesiewaczy wyposażonych w klasyczne układy napędowe.
\end{abstract}

Słowa kluczowe: przesiewacz laboratoryjny, układ napędowy przesiewacza, pomiar amplitudy drgań, trajektoria drgań, modernizacja przesiewacza

\section{INFLUENCE OF THE TYPE OF DRIVE OF THE LABORATORY SCREEN WITH RECTILINEAR VIBRATIONS ON THE PARAMETERS OF ITS WORK IN THE STEADY STATE}

\begin{abstract}
The paper presents the results of research on the vibrational motion of a laboratory sifter with a rectilinear (segmental) vibration trajectory. The aim of the research was to indicate the differences resulting from the applied variant of the screener vibration induction system. These variants were: a classic system (two asynchronous motors driving inertia vibrators with tire clutches) and a system of two vibration motors used in newer solutions of industrial screens - attached directly to the riddle. The tests, which consisted in measuring the vibration amplitudes and their trajectories at selected measurement points located on the screen frame, were carried out for three different vibration frequencies - the same for different drive systems. The obtained test results confirmed the purposefulness of modernizing older screen structures equipped with classic drive systems.
\end{abstract}

Keywords: laboratory screen, screen drive system, vibration amplitude measurement, vibration trajectory, screen modernization

https://doi.org/10.7494/978-83-66727-48-9_11 


\section{Wprowadzenie}

Znaczna część surowców mineralnych wydobywanych w Polsce i na świecie to kopaliny stałe. Wśród surowców mineralnych ważną grupę stanowią kruszywa. Wykorzystanie ich w przemyśle wymaga prowadzenia procesów przeróbki, takich jak np. rozdrabnianie, granulacja, przesiewanie, suszenie i oczyszczanie. Procesy te podnoszą wartość użytkową kruszywa (Banaszewski i in. 2007, Feliks i Filipowicz 2008, 2009) Jednym z najistotniejszych paramentów opisujących jakość kruszywa jest jednorodny skład ziarnowy, dlatego istotna jest dokładna klasyfikacja ziarnowa znacznej części kruszyw. Podstawowym wyposażeniem zdecydowanej większości zakładów przeróbki kopalin są przesiewacze wibracyjne (Sidor i in. 2015). Służą one do wyodrębnienia z danego kruszywa określonej klasy ziarnowej o pożądanych wielkościach ziaren, jak również mogą oczyszczać produkt z zanieczyszczeń. Najbardziej rozpowszechnionym typem przesiewaczy są urządzenia wibracyjne o drganiach kołowych (WK) i prostoliniowych (WP) rzadziej o drganiach eliptycznych (PZ, PWE) (Banaszewski 1990).

Najbardziej rozpowszechnionymi przesiewaczami stosowanymi w praktyce przemysłowej są przesiewacze wibracyjne sitowe. Na rysunku 1 zaprezentowano kilka standardowych rozwiązań konstrukcyjnych przesiewaczy wibracyjnych.

a)

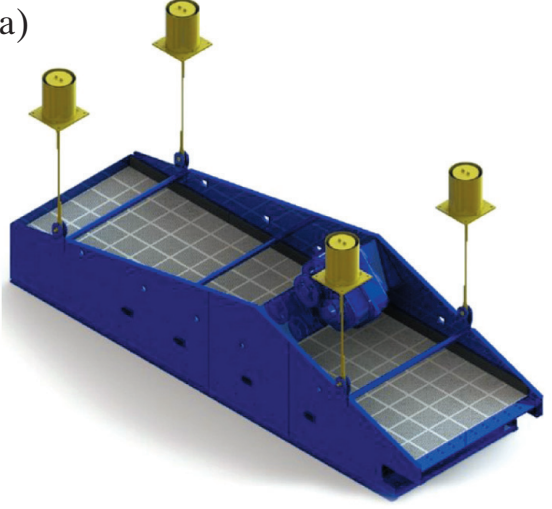

c)

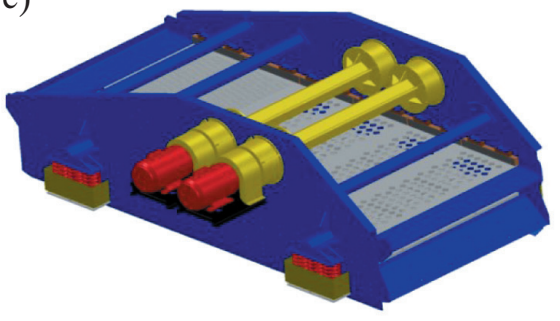

b)

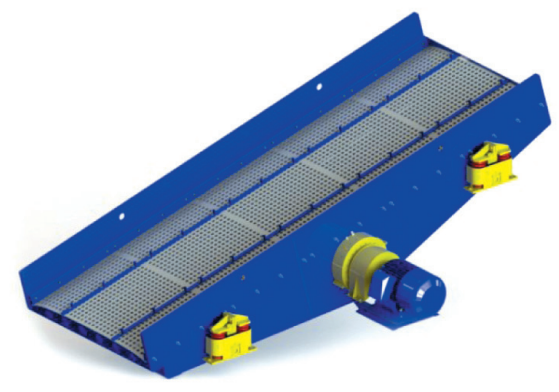

d)

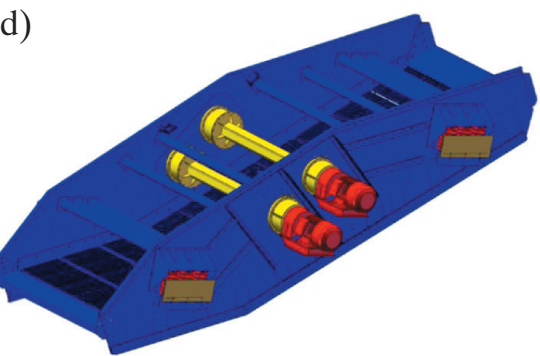

Rys. 1. Przykładowe konstrukcje najpopularniejszych przesiewaczy przemysłowych:

a) WP; b) WK; c) PWE; d) PZ

Źródło: MIFAMA (b.d.), CARBOAUTOMATYKA (b.d.) 
Za wprowadzenie przesiewacza w ruch drgający odpowiedzialny jest układ napędowy, którego zadaniem jest wygenerowanie siły harmonicznej, a następnie przekazanie jej na rzeszoto, gdzie zamieniana jest ona na drgania kołowe lub prostoliniowe. Układ napędowy, w klasycznych oraz starszych konstrukcjach, składa się najczęściej z silnika elektrycznego, sprzęgieł elastycznych oraz wibratora. Najpopularniejszymi jednostkami napędowymi stosowanymi w przesiewaczach są silniki elektryczne asynchroniczne. Ich umiejscowienie na maszynie zależy od wielu czynników, takich jak: wielkość przesiewacza, rodzaj przesiewacza i wibratora, konstrukcja ramy wsporczej i rzeszota czy usytuowanie przesiewacza w ciągu technologicznym maszyn. W niektórych rozwiązaniach konstrukcyjnych za wymuszenie ruchu drgającego odpowiedzialne są silniki wibracyjne mocowane bezpośrednio do rzeszota. Należy jednak podkreślić, że jednostki te narażone są na dodatkowe siły bezwładności, dlatego wymagają zastosowania wzmocnionych łożysk w celu przedłużenia ich żywotności i uniknięcia szybkiej awarii. Zaletą montowania silników poza rzeszotem jest brak działania na nie sił wynikających z ruchu drgającego, jednak w celu doprowadzenia momentu obrotowego do wibratora niezbędne jest zastosowanie dodatkowych sprzęgieł lub przekładni. Najczęściej wykorzystywane są przekładnie pasowe, które amortyzują drgania pochodzące od wibratora. Do mocowania elementów układu napędowego na konstrukcji sztywnej stosuje się sprzęgła elastyczne oraz sztywne, natomiast w celu doprowadzenia momentu obrotowego do wibratora wykorzystuje się sprzęgła wychylne. Zaliczyć do nich można sprzęga typu oponowego oraz Cardana.

Elementem maszyny, który bezpośrednio odpowiada za powstawanie drgań, jest wibrator. W przesiewaczach stosowane powszechnie są dwa rodzaje wibratorów: mimośrodowe i bezwładnościowe. Wibratory bezwładnościowe stosowane są głównie w przesiewaczach pracujących nadrezonansowo. Amplituda drgań uzależniona jest od siły odśrodkowej pochodzącej od wszystkich mas niewyważonych osadzonych na wałach wibratora (Dietrych 1962, Banaszewski 1990).

\section{Stanowisko badawcze}

Badania przeprowadzono na laboratoryjnym przesiewaczu wibracyjnym WP, w którym zastosowany jest podwieszony system zawieszenia znajdujący się w górnej części ramy (tzw. przesiewacz podwieszany). W nowoczesnych przesiewaczach taki układ jest rzadko stosowany ze względu na brak możliwość szybkiej i łatwiej wymiany w przypadku awarii. Podwieszany system zawieszenia ma jednak istotną zaletę: eliminuje poziome oddziaływanie dynamiczne na konstrukcję nośną przesiewacza. 
W skład stanowiska badawczego wchodziły:

- laboratoryjny podwieszany przesiewacz WP z możliwością wymuszenia ruchu drgającego dla dwóch wersji napędu:

- klasyczny układ napędowy (silnik - sprzęgło elastyczne - wibrator),

- silniki wibracyjne mocowane bezpośrednio do rzeszota,

- układ pomiarowy drgań.

\subsection{Klasyczny układ napędowy}

Laboratoryjny przesiewacz WP z klasyczną wersją napędu wyposażony jest w dwumasowy, samosynchronizujący się wibrator bezwładnościowy. Regulacja trajektorii drgań możliwa jest dzięki zmianie położenia wibratorów (miejsca ich montażu na rzeszocie), a wartość amplitudy może być regulowana w zależności od liczby założonych mas niewyważonych w wibratorze. Prędkość obrotowa wałów napędowych wynosi 960 obr/min i może być zmieniana dzięki zastosowaniu tyrystorowych przemienników częstotliwości. Widok stanowiska badawczego przedstawiono na rysunku 2.
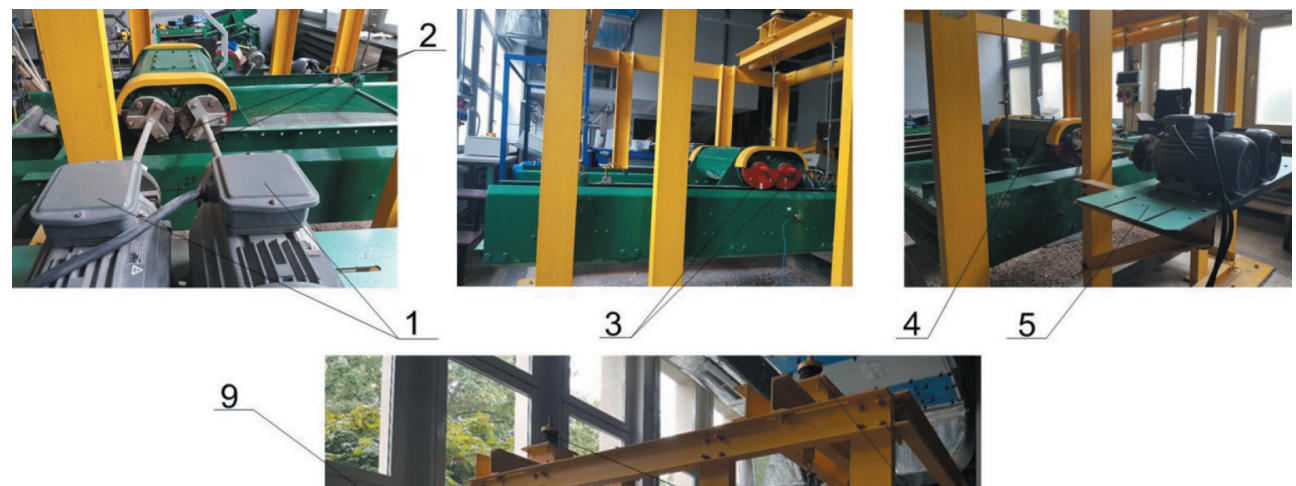

8

3

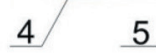

5

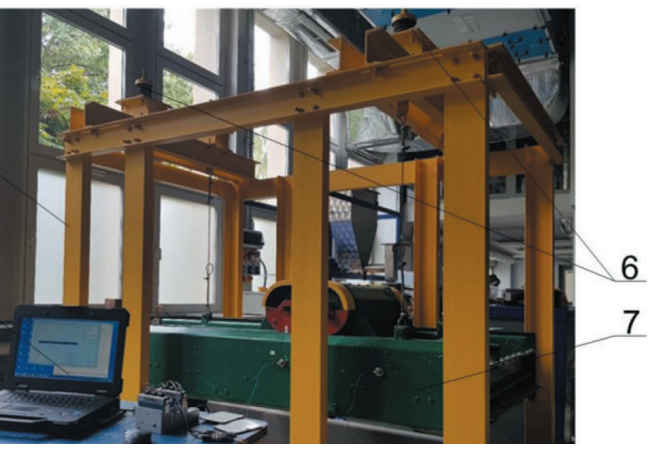

Rys. 2. Widok przesiewacza laboratoryjnego WP z klasyczną wersją układu napędowego: 1 - silnik, 2 - wał wraz ze sprzęgłami elastycznymi, 3 - masy niewyważone, 4 - obudowa wibratora, 5 - konstrukcja wsporcza silników, 6 - zawieszenie sprężyste, 7 - rzeszoto, 8 - układ pomiarowy drgań, 9 - rama

Układ napędowy w laboratoryjnym przesiewaczu wibracyjnym składa się z: dwóch silników elektrycznych o mocy $1,5 \mathrm{~kW}$, dwóch sprzęgieł elastycznych gumowych oraz dwumasowego wibratora bezwładnościowego, którego model przedstawiono na rysunku 3. 
Wibrator ten zbudowany jest z dwóch wałów, na których osadzone są masy niewyważone. Na każdym wale znajdują się dwie masy półpierścieniowe oznaczone, na rysunku 3, numerami 1 i 3 . Pomiędzy nimi mieści się podłużna masa 2 składająca się z trzech kształtowników. Całość zamknięta jest w jednolitej obudowie, zapewniającej względną szczelność i ochronę przed zanieczyszczeniami. Czopy końcowe wału mają gniazda pod wpust pryzmatyczny przenoszący moment obrotowy - za pośrednictwem sprzęgieł elastycznych gumowych (pozwalających na występowanie niewspółosiowości w układzie oraz zabezpieczających silniki elektryczne przed drganiami wibratora).

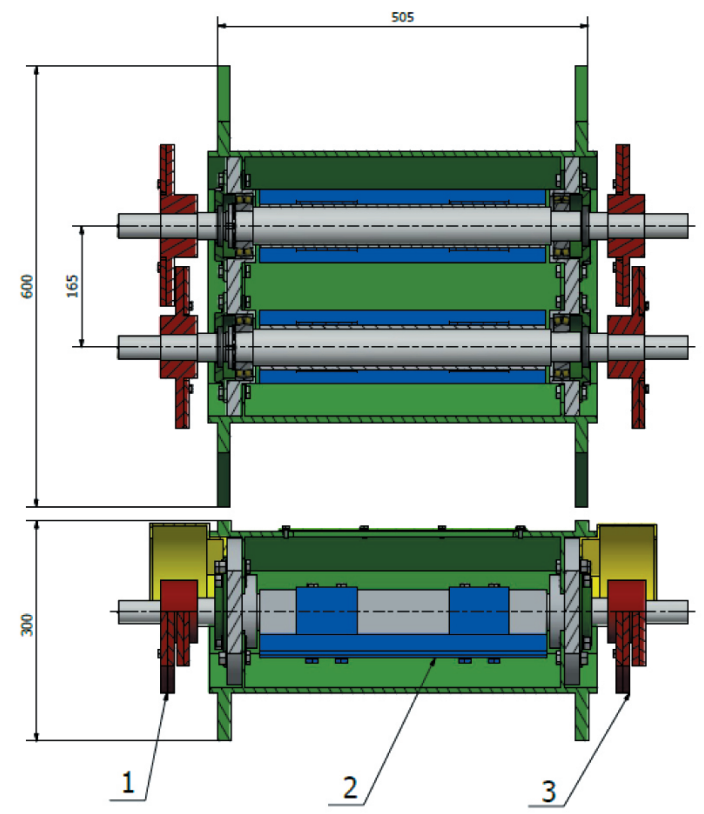

Rys. 3. Model wibratora bezwładnościowego przesiewacza laboratoryjnego WP (opis w tekście)

Wibrator bezwładnościowy przymocowany jest do blach bocznych rzeszota za pomocą śrub. Otwory w blachach wykonane są w regularnych odstępach, na całej długości przesiewacza, co sprawia, że operator ma możliwość zmiany położenia wibratora wzdłuż rzeszota. Laboratoryjny przesiewacz wibracyjny, za pomocą omówionego dwumasowego wibratora bezwładnościowego z symetrycznie rozmieszczonymi masami niewyważonymi, wprawiany jest w prostoliniowy ruch drgający (efekt samosynchronizacji wałów wibratora).

\subsection{Układ napędowy oparty na silnikach wibracyjnych}

W omówionym we wcześniejszym podrozdziale stanowisku przesiewacza klasyczny układ napędowy zastąpiono układem dwóch silników wibracyjnych zamontowanych na płycie wsporczej (w tym samym miejscu co wibratory w układzie klasycznym). 
Silniki wibracyjne (elektrowibratory) wyposażone są w dwa obustronnie wystające z silnika czopy wału, na których zamontowane są masy niewyważone. Całość zamknięta jest w kompaktowej obudowie pozwalającej umieścić silnik wibracyjny w dowolnym miejscu maszyny. Zamknięty korpus urządzenia sprawia również, że może ono pracować w ciężkich warunkach - w obecności kurzu lub wilgoci, a nawet w środowisku zagrożonym wybuchem. Silniki te wyróżniają się stosunkowo dużymi łożyskami, co wynika z przenoszenia znacznych sił poprzecznych pochodzących od mas niewyważonych oraz naprężeń wynikających z drgań całego układu. Producenci zazwyczaj umieszczają na jednym czopie masy niewyważone stałe i nastawne. Moment statyczny, a tym samym wartość siły wymuszającej drgania mogą być dzięki temu regulowane. Widok przykładowego silnika wibracyjnego przedstawiono na rysunku 4 (Będkowski 2019).

a)

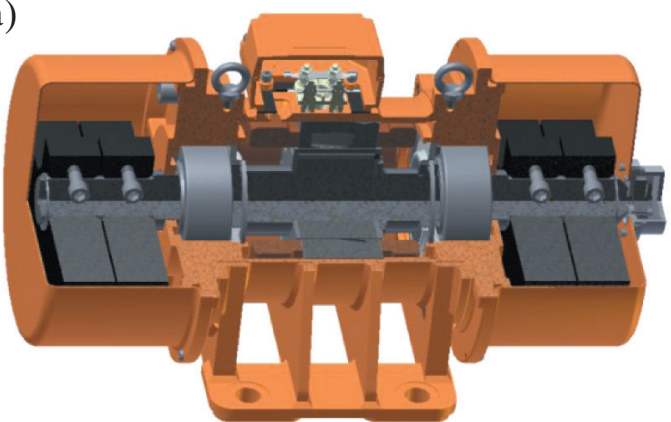

b)

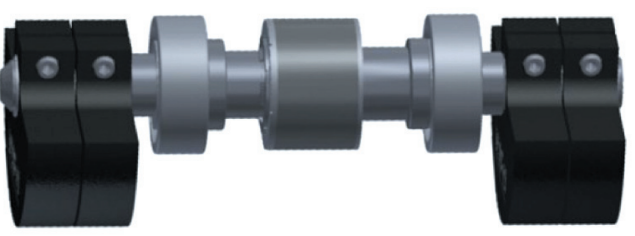

Rys. 4. Model silnika wibracyjnego z nastawnymi masami niewyważonymi: a) widok silnika wibracyjnego; b) widok wirnika

W tym wariancie napędu przesiewacz laboratoryjny WP wprawiany jest w ruch drgający przez dwa silniki wibracyjne. Po przeprowadzeniu obliczeń mających na celu dobór właściwego silnika (generowania przez silnik odpowiedniej wartości siły odśrodkowej) dobrano silnik typu 510/1 firmy Qnisz. Podstawowe parametry zastosowanego elektrowibratora przedstawiono w tabeli 1 (jednostki fizyczne w tabeli podano w sposób oryginalny - zaproponowany przez producenta) (Qnisz ING, b.d.).

Laboratoryjny przesiewacz WP z silnikami wibracyjnymi MVE 510/1 umieszczonymi na płycie wsporczej przedstawiono na rysunku 5.

Ulokowanie elektrowibratorów w bliskiej odległości na jednej płycie zapewnia ich pełną synchronizację oraz w efekcie ruch prostoliniowy przesiewacza. Dzięki zastoso- 
waniu takiego wariantu napędu szerokość przesiewacza została zmniejszona, w porównaniu z klasycznym układem napędowym, o np. 30\%, a masa zespołu napędowego zredukowana o $40 \mathrm{~kg}$.

Tabela 1

Podstawowe parametry elektrowibratora MVE 510/1

\begin{tabular}{|c|c|c|c|c|c|c|c|c|}
\hline \multicolumn{5}{|c|}{ Właściwości mechaniczne } & \multicolumn{4}{|c|}{ Właściwości elektryczne } \\
\hline \multicolumn{2}{|c|}{$\begin{array}{c}\text { moment pracy } \\
{[\mathrm{kg} \cdot \mathrm{cm}]}\end{array}$} & \multicolumn{2}{|c|}{$\begin{array}{c}\text { siła wymuszająca } \\
{[\mathrm{kg}]}\end{array}$} & \multirow{2}{*}{$\begin{array}{c}\text { waga } \\
{[\mathrm{kg}]}\end{array}$} & \multicolumn{2}{|c|}{$\begin{array}{l}\operatorname{moc} \\
{[\mathrm{kW}]}\end{array}$} & \multicolumn{2}{|c|}{$\begin{array}{l}\text { prąd maks. }(Y) \\
{[\mathrm{A}]}\end{array}$} \\
\hline $50 \mathrm{~Hz}$ & $60 \mathrm{~Hz}$ & $50 \mathrm{~Hz}$ & $60 \mathrm{~Hz}$ & & $50 \mathrm{~Hz}$ & $60 \mathrm{~Hz}$ & $50 \mathrm{~Hz}$ & $60 \mathrm{~Hz}$ \\
\hline 91,88 & 91,88 & 513 & 739 & 34,5 & 0,35 & 0,40 & 1,20 & 1,15 \\
\hline
\end{tabular}

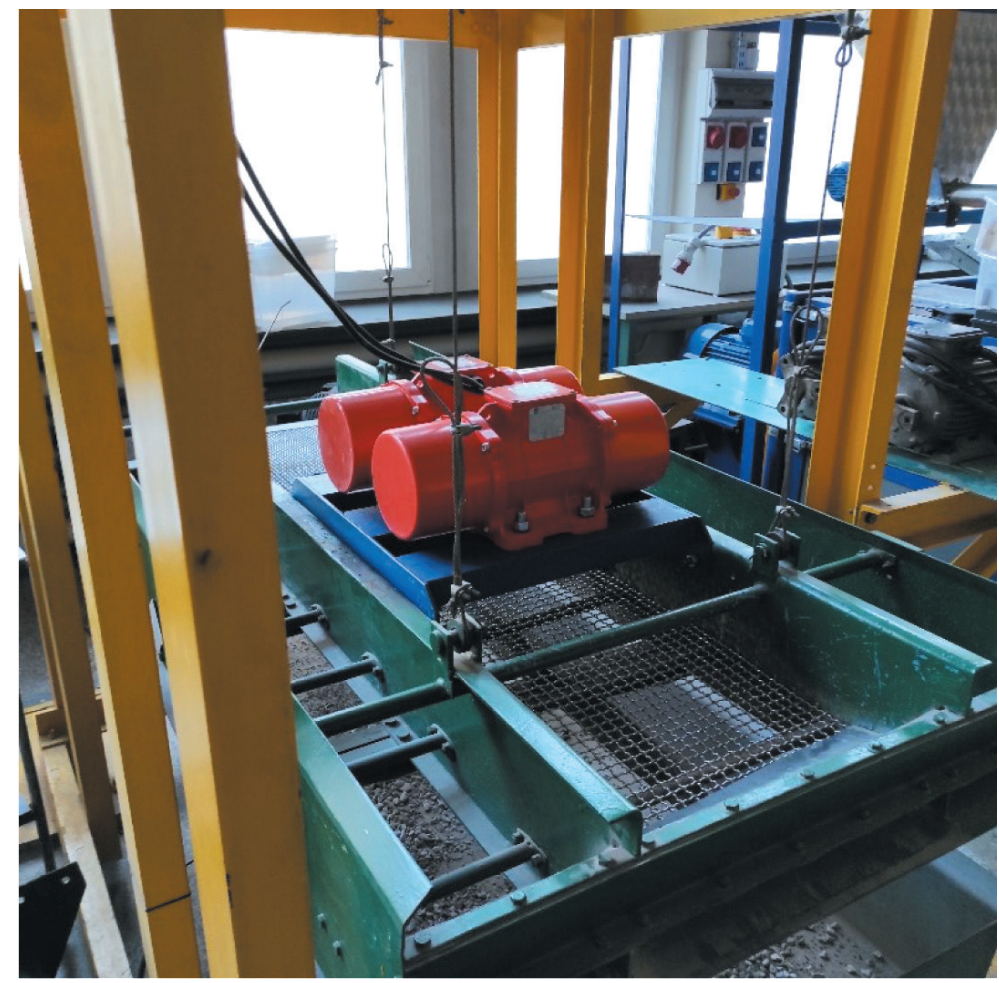

Rys. 5. Widok przesiewacza z układem napędowym zawierającym silniki wibracyjne MVE 510/1

\subsection{Pomiar parametrów ruchu drgającego}

Badania wybranych parametrów ruchu drgającego, dla obu wariantów układu napędowego, przesiewacza WP wykonano w trzech charakterystycznych punktach 
umieszczonych po obu stronach rzeszota (symetrycznie względem płaszczyzny symetrii pomiędzy burtami rzeszota, tj. po lewej i prawej stronie rzeszota, patrząc od strony wylotu produktu z przesiewacza). Punkty te oznaczono cyframi od 1 do 3 oraz, w zależności od tego, po której stronie rzeszota się znajdują, oznaczono je literami „L” lub „P” - np. 1L, 1P.

Wszystkie punkty znajdowały się na wysokości pokładu sitowego oraz tak, że:

- punkty 1L i 1P pokrywają się z płaszczyzną prostopadłą do burty rzeszota przechodzącą przez punkty podwieszenia rzeszota znajdujących się bliżej strony rozładowczej przesiewacza;

- punkty 2L i 2P pokrywają się z płaszczyzną prostopadłą do burty rzeszota będącą jednocześnie płaszczyzną symetrii układu napędowego (równoległą do osi wibratorów);

- punkty 3L i 3P pokrywają się z płaszczyzną prostopadłą do burty rzeszota przechodzącą przez punkty podwieszenia rzeszota znajdujących się od strony wlotu nadawy na pokład sitowy.

Widok niektórych z wytypowanych punktów przedstawiono na rysunku 6 .

a)

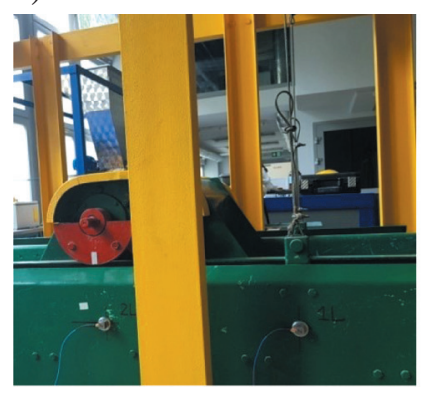

b)

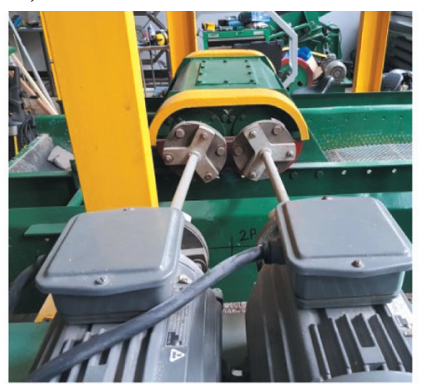

c)

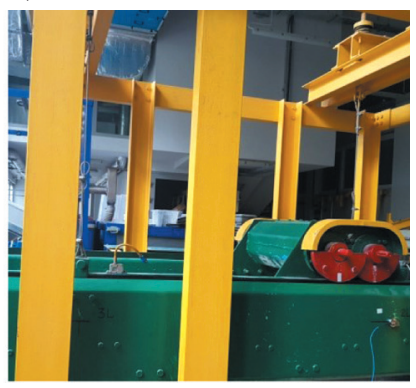

Rys. 6. Widok wytypowanych punktów pomiarowych zaznaczonych na powierzchni rzeszota laboratoryjnego przesiewacza WP: a) punkty $1 \mathrm{~L}, 2 \mathrm{~L}$; b) punkt 2P; c) punkt $3 \mathrm{~L}$ i $2 \mathrm{~L}$

Do badań parametrów ruchu drgającego wykorzystano układ pomiarowy oparty na trójosiowych czujnikach przyspieszeń. Widok tego stanowiska przedstawiono na rysunku 7. Głównymi elementami układu były:

- karty pomiarowe NI 9232 3-Ch zabudowane w obudowie Compact DAQ cDAQ-9174,

- trójosiowe, piezoelektryczne czujniki przyspieszeń PCB 356A02,

- komputer pomiarowy DELL Latitude Rugged Extreme 7404 z niezbędnym oprogramowaniem.

W badaniach wykorzystano oprogramowanie pozwalające m.in. na zobrazowanie trajektorii drgań oraz przebiegów czasowych przyspieszeń. 


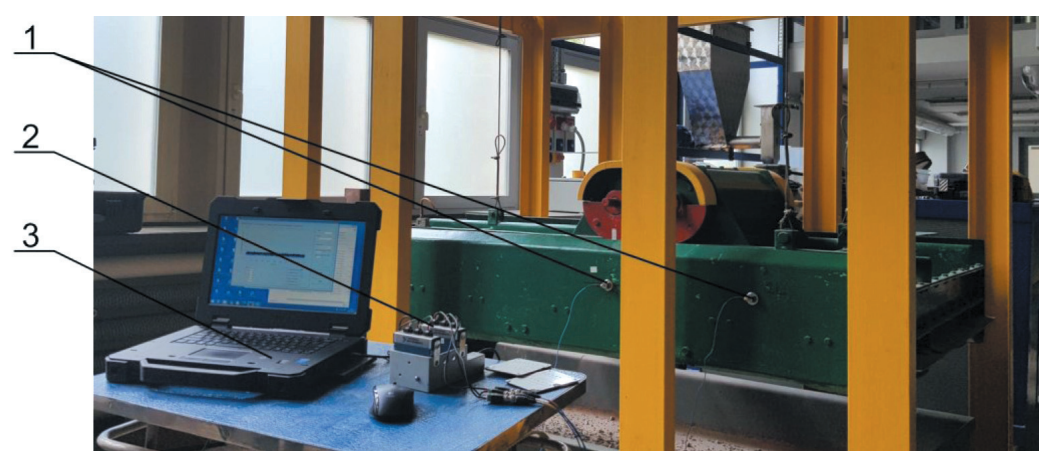

Rys. 7. Stanowisko w trakcie pomiaru drgań: 1 - czujniki przyspieszeń, 2 - karty pomiarowe, 3 - komputer pomiarowy

\section{Badania eksperymentalne}

Głównym celem przeprowadzonych badań było wykazanie wpływu rodzaju zastosowanego napędu przesiewacza WP na wybrane parametry ruchu drgającego dla trzech częstotliwości drgań przesiewacza. Program badań obejmował wyznaczenie, w sześciu charakterystycznych punktach przesiewacza WP (opisanych w we wcześniejszym podrozdziale), dla obu wariantów zastosowanego układu napędowego, następujących parametrów ruchu drgającego przesiewacza:

- amplitudy drgań (trajektoria, wartości maksymalne na kierunku $X-A_{x}$ i $Y-A_{y}$ ),

- przebiegu czasowego amplitudy drgán.

Badania przeprowadzono dla trzech wartości częstotliwości drgań: 13,2 Hz, 16,5 Hz oraz 19,8 Hz, co odpowiadało nastawom przemiennika częstotliwości: $40 \mathrm{~Hz}$, $50 \mathrm{~Hz}$ i $60 \mathrm{~Hz}$.

Badania zostały podzielone na dwa etapy. Etap pierwszy obejmował badania klasycznego układu napędowego opisanego w podrozdziale 2.1, a etap - drugi badania układu napędowego opartego na silnikach wibracyjnych opisanego w podrozdziale 2.2 .

\subsection{Wyniki badań przesiewacza WP z wykorzystaniem klasycznego układu napędowego}

$\mathrm{W}$ pierwszym etapie badania przeprowadzono z wykorzystaniem przesiewacza WP z klasycznym układem napędowym. Na rysunku 8 przestawiono widok trajektorii drgań zarejestrowanej podczas pracy ustalonej przesiewacza dla częstotliwości drgań 16,5 Hz dla wszystkich punktów pomiarowych, co ma na celu zobrazowanie ewentualnych różnic w charakterystyce trajektorii amplitudy drgań po obu stronach rzeszota. 


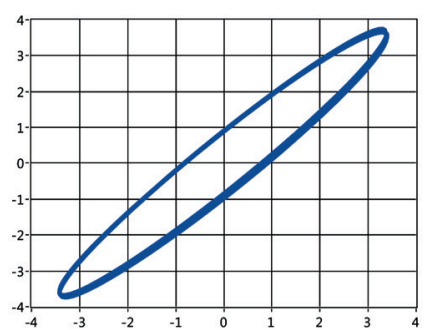

$3 \mathrm{~L}$

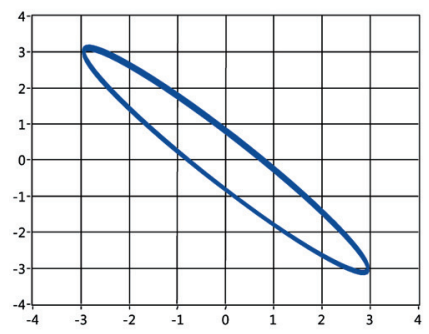

3P

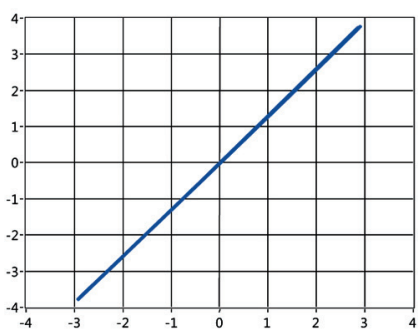

$2 \mathrm{~L}$

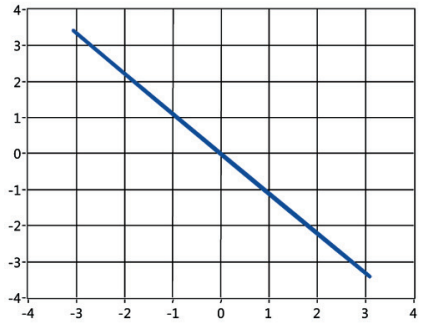

$2 \mathrm{P}$

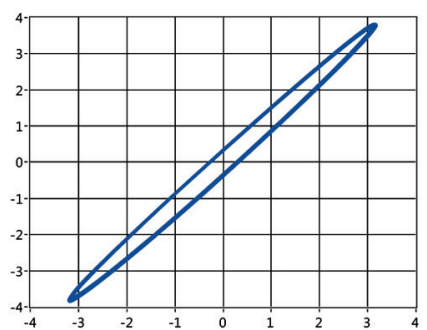

$1 \mathrm{~L}$

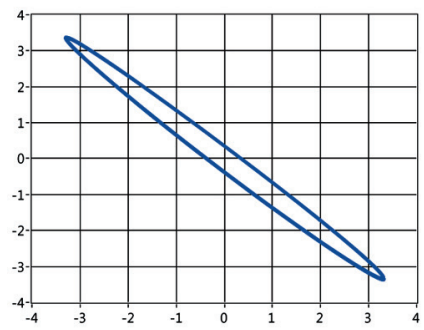

1P

Rys. 8. Widok kreślonej trajektorii drgań dla punktów pomiarowych przy $f=16,5 \mathrm{~Hz}$

Przykładową charakterystykę czasową amplitudy drgań, dla punktu pomiarowego $2 \mathrm{~L}$ przy częstotliwości drgań $16,5 \mathrm{~Hz}$, zaprezentowano na rysunku 9, gdzie kolorem niebieskim oznaczono przebieg amplitudy na kierunku pionowym $\left(A_{x}\right)$, a kolorem czerwonym na kierunku poziomym $\left(A_{y}\right)$.

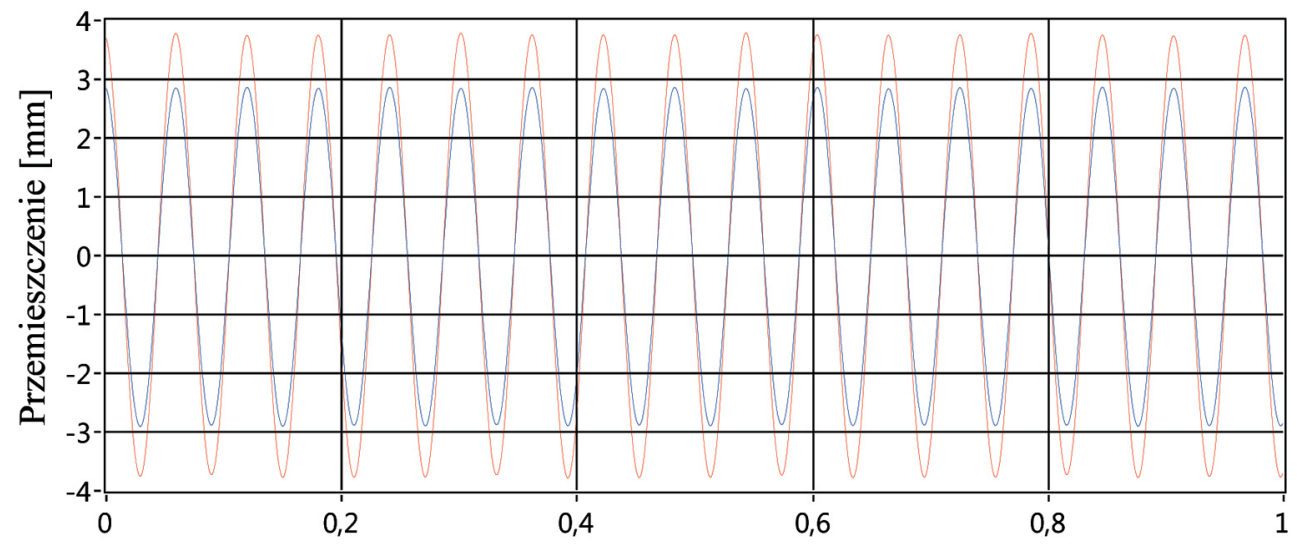

Rys. 9. Charakterystyka czasowa amplitudy drgań przesiewacza w punkcie $2 \mathrm{~L}$ dla częstotliwości drgań $16,5 \mathrm{~Hz}$ w stanie ustalonym

W tabeli 2 przedstawiono, zbiorczo, wyniki badań wartości maksymalnych amplitud na kierunku poziomym $\left(A_{x}\right)$ oraz pionowym $\left(A_{y}\right)$ dla wszystkich punktów pomiarowych i dla trzech wartości częstotliwości drgań przesiewacza $(f)$. 
Tabela 2

Wartości amplitud drgań dla klasycznego układu napędowego podczas pracy przesiewacza $\mathrm{w}$ stanie ustalonym

\begin{tabular}{|c|c|c|c|c|c|c|c|c|c|c|c|c|}
\hline \multirow{3}{*}{$\begin{array}{c}f \\
{[\mathrm{~Hz}]}\end{array}$} & \multicolumn{10}{|c|}{ Punkt pomiarowy } \\
\cline { 2 - 14 } & $\begin{array}{c}|c| \\
A_{x} \\
{[\mathrm{~mm}]}\end{array}$ & $\begin{array}{c}A_{y} \\
{[\mathrm{~mm}]}\end{array}$ & $\begin{array}{c}A_{x} \\
{[\mathrm{~mm}]}\end{array}$ & $\begin{array}{c}A_{y} \\
{[\mathrm{~mm}]}\end{array}$ & $\begin{array}{c}A_{x} \\
{[\mathrm{~mm}]}\end{array}$ & $\begin{array}{c}A_{y} \\
{[\mathrm{~mm}]}\end{array}$ & $\begin{array}{c}A_{x} \\
{[\mathrm{~mm}]}\end{array}$ & $\begin{array}{c}A_{y} \\
{[\mathrm{~mm}]}\end{array}$ & $\begin{array}{c}A_{x} \\
{[\mathrm{~mm}]}\end{array}$ & $\begin{array}{c}A_{y} \\
{[\mathrm{~mm}]}\end{array}$ & $\begin{array}{c}A_{x} \\
{[\mathrm{~mm}]}\end{array}$ & $\begin{array}{c}A_{y} \\
{[\mathrm{~mm}]}\end{array}$ \\
\hline 13,2 & 3,57 & 3,12 & 3,29 & 3,30 & 3,77 & 3,85 & 3,70 & 2,79 & 3,46 & 3,06 & 3,56 & 3,68 \\
\hline 16,5 & 3,18 & 3,81 & 2,90 & 3,76 & 3,41 & 3,70 & 3,32 & 3,37 & 3,08 & 3,42 & 3,20 & 3,43 \\
\hline 19,8 & 3,01 & 3,95 & 2,75 & 3,83 & 3,22 & 3,60 & 3,15 & 3,59 & 2,91 & 3,56 & 3,04 & 3,35 \\
\hline
\end{tabular}

W związku z tym że niniejszy artykuł dotyczy parametrów pracy przesiewacza w stanie ustalonym, każdy z przeprowadzonych pomiarów wykonywany był wyłącznie po ustabilizowaniu się pracy maszyny.

Na rysunku 10 przedstawiono porównanie zarejestrowanych wartości amplitud na kierunku poziomym w funkcji częstotliwości drgań we wszystkich badanych punktach (linią ciągłą oznaczono punkty po „lewej” stronie przesiewacza, a linią przerywaną po „prawej” stronie), natomiast na rysunku 11 - analogiczne zestawienie dla amplitud na kierunku pionowym.

Kolejny etap badań parametrów ruchu drgającego, w wytypowanych sześciu punktach, dotyczył przesiewacza WP z układem napędowym opartym na dwóch silnikach wibracyjnych opisanych w podrozdziale 2.2.

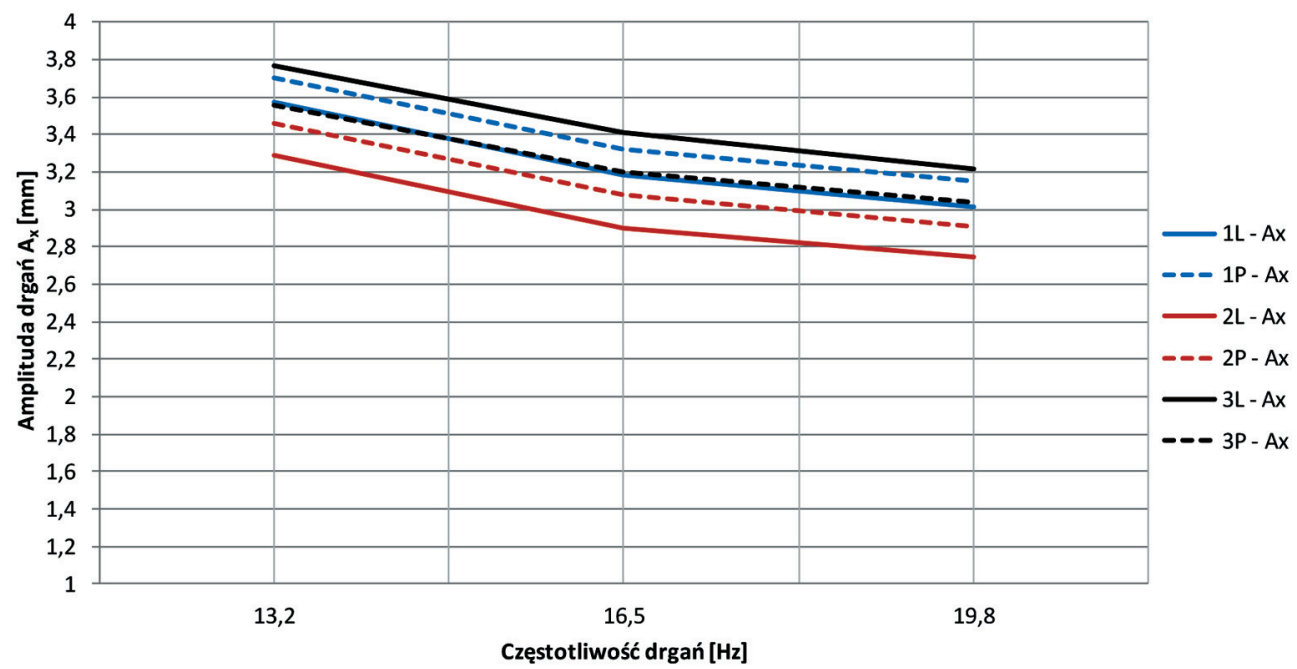

Rys. 10. Zmiana wartości amplitud $A_{x}$ jako funkcja częstotliwości drgań w klasycznym układzie napędowym przesiewacza WP 


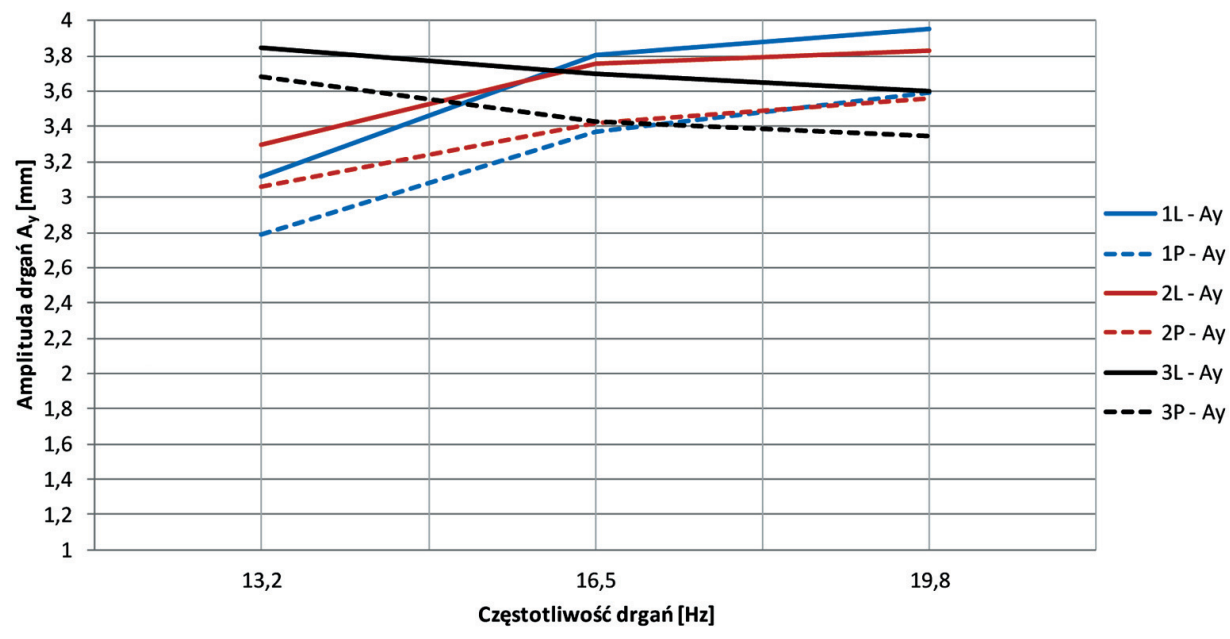

Rys. 11. Zmiana wartości amplitud $A_{y}$ jako funkcja częstotliwości drgań w klasycznym układzie napędowym przesiewacza WP

\subsection{Wyniki badań przesiewacza WP z układem napędowym składającym się z silników wibracyjnych}

Na rysunku 12 przedstawiono widok trajektorii drgań zarejestrowanej podczas pracy ustalonej przesiewacza przy częstotliwości drgań $16,5 \mathrm{~Hz}$ dla wszystkich punktów pomiarowych. W tabeli 3 przedstawiono, zbiorczo, wyniki badań.

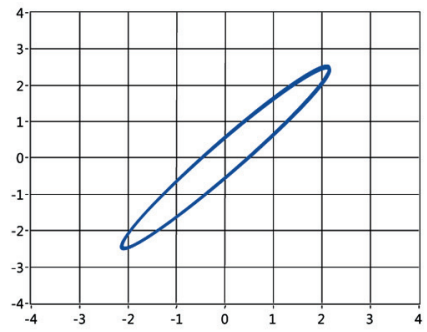

$3 \mathrm{~L}$

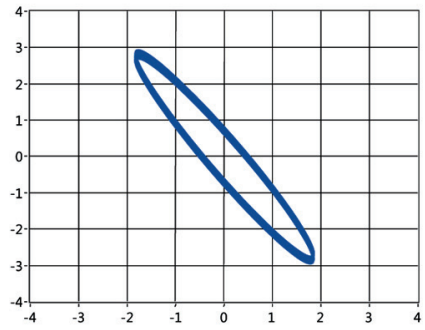

$3 P$

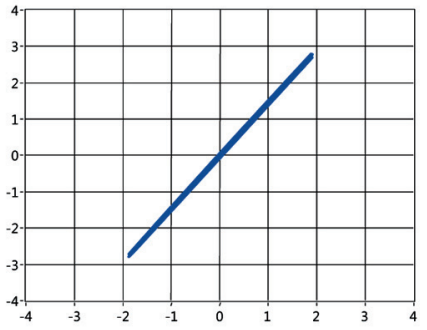

$2 \mathrm{~L}$

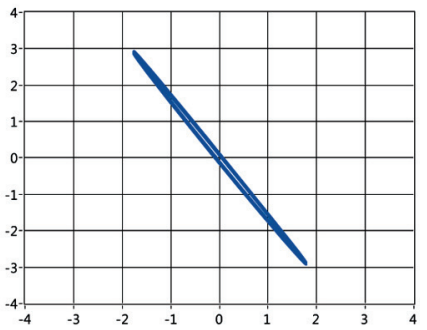

$2 \mathrm{P}$

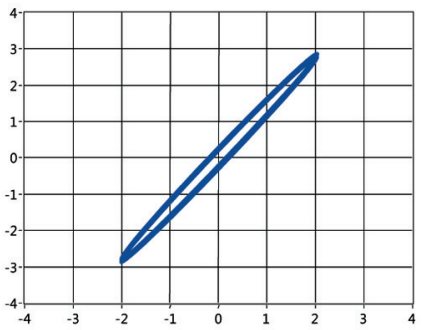

$1 \mathrm{~L}$

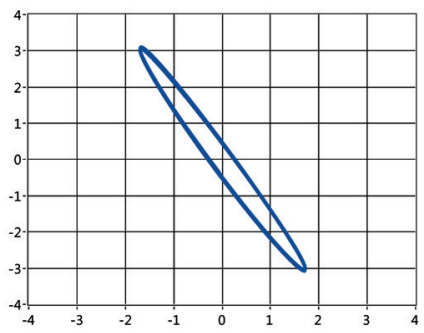

$1 \mathrm{P}$

Rys. 12. Widok kreślonej trajektorii drgań dla punktów pomiarowych $\operatorname{przy} f=16,5 \mathrm{~Hz}$ 
Tabela 3

Wartości amplitud drgań dla układu napędowego zbudowanego z dwóch silników wibracyjnych podczas pracy przesiewacza $\mathrm{w}$ stanie ustalonym

\begin{tabular}{|c|c|c|c|c|c|c|c|c|c|c|c|c|}
\hline \multirow{3}{*}{$\begin{array}{c}f \\
{[\mathrm{~Hz}]}\end{array}$} & \multicolumn{10}{|c|}{$1 \mathrm{~L}$} & \multicolumn{10}{|c|}{$2 \mathrm{~L}$} & \multicolumn{2}{|c|}{$3 \mathrm{~L}$} & \multicolumn{2}{|c|}{$1 \mathrm{P}$} & \multicolumn{2}{|c|}{$2 \mathrm{P}$} & \multicolumn{2}{c|}{$3 \mathrm{P}$} \\
\cline { 2 - 14 } & $\begin{array}{c}A_{x} \\
{[\mathrm{~mm}]}\end{array}$ & $\begin{array}{c}A_{y} \\
{[\mathrm{~mm}]}\end{array}$ & $\begin{array}{c}A_{x} \\
{[\mathrm{~mm}]}\end{array}$ & $\begin{array}{c}A_{y} \\
{[\mathrm{~mm}]}\end{array}$ & $\begin{array}{c}A_{x} \\
{[\mathrm{~mm}]}\end{array}$ & $\begin{array}{c}A_{y} \\
{[\mathrm{~mm}]}\end{array}$ & $\begin{array}{c}A_{x} \\
{[\mathrm{~mm}]}\end{array}$ & $\begin{array}{c}A_{y} \\
{[\mathrm{~mm}]}\end{array}$ & $\begin{array}{c}A_{x} \\
{[\mathrm{~mm}]}\end{array}$ & $\begin{array}{c}A_{y} \\
{[\mathrm{~mm}]}\end{array}$ & $\begin{array}{c}A_{x} \\
{[\mathrm{~mm}]}\end{array}$ & $\begin{array}{c}A_{y} \\
{[\mathrm{~mm}]}\end{array}$ \\
\hline 13,2 & 2,45 & 2,31 & 2,01 & 2,61 & 2,38 & 2,69 & 2,16 & 2,69 & 2,21 & 2,58 & 2,05 & 3,02 \\
\hline 16,5 & 2,03 & 2,84 & 1,89 & 2,76 & 2,15 & 2,50 & 1,71 & 3,07 & 1,77 & 2,90 & 1,84 & 2,84 \\
\hline 19,8 & 2,09 & 2,93 & 1,61 & 2,94 & 1,95 & 2,28 & 1,77 & 3,05 & 1,86 & 2,82 & 1,69 & 2,81 \\
\hline
\end{tabular}

Porównanie zarejestrowanych wartości maksymalnych amplitud na kierunku poziomym w funkcji częstotliwości drgań we wszystkich badanych punktach przedstawiono na rysunku 13. Na wykresie tym linią ciągłą oznaczono punkty po lewej stronie przesiewacza (1L, 2L, 3L), a linią przerywaną po jego prawej stronie (1P, 2P, 3P). Analogiczne zestawienie dla amplitud na kierunku pionowym przedstawiono na rysunku 14.

Ze względu na ograniczoną objętość artykułu przedstawione wyniki badań dotyczą tylko pracy w stanie ustalonymi i nie traktują o różnicach wynikajaccych z wpływu rodzaju zastosowanego napędu na parametry ruchu drgającego w trakcie rozruchu i zatrzymania przesiewacza - stanowi to odrębne i obszerne zagadnienie, które powinno być przedmiotem odrębnego artykułu.

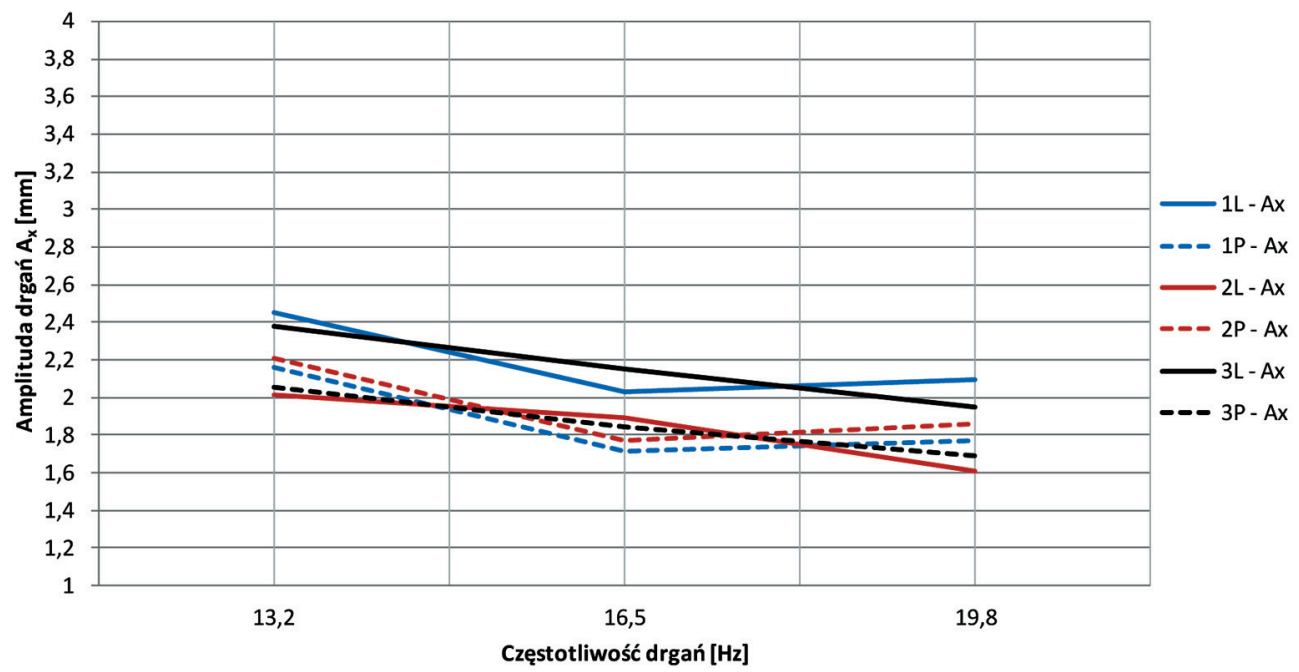

Rys. 13. Zmiana wartości amplitud $A_{x}$ jako funkcja częstotliwości drgań w układzie napędowym zbudowanym $\mathrm{z}$ dwóch silników wibracyjnych 


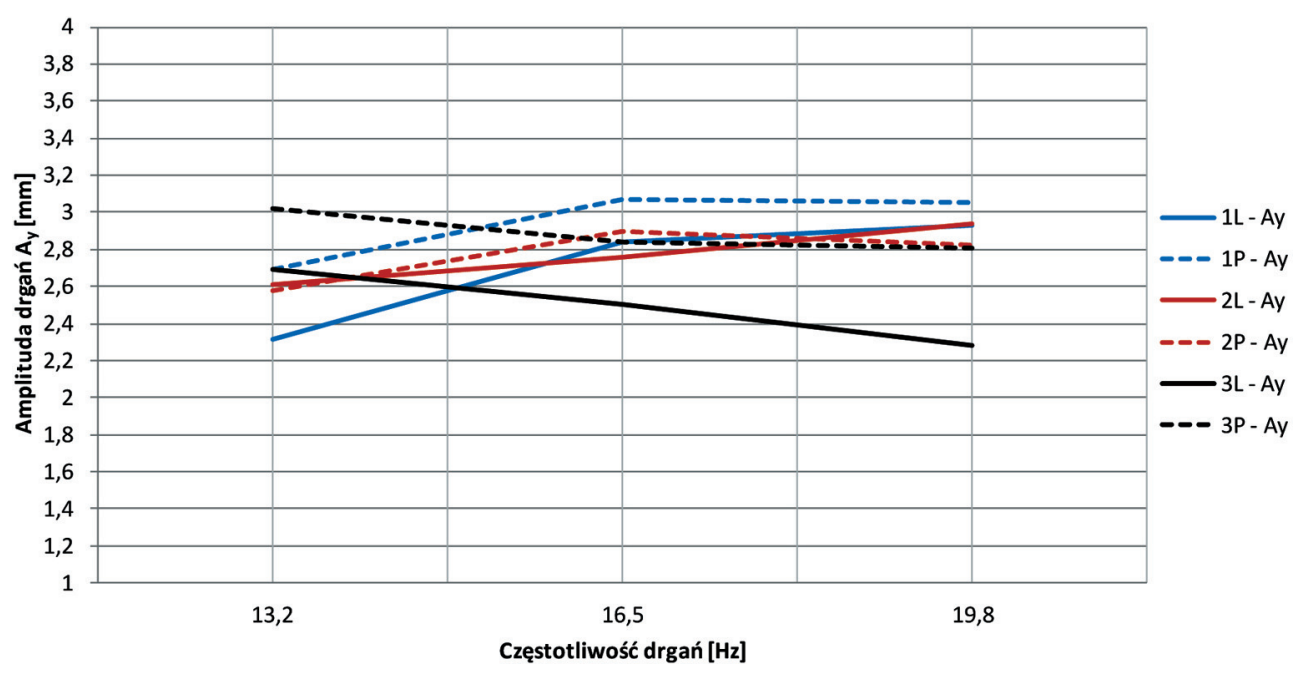

Rys. 14. Zmiana wartości amplitud $A_{y}$ jako funkcja częstotliwości drgań w układzie napędowym zbudowanym z dwóch silników wibracyjnych

\section{Podsumowanie wyników badań i wnioski}

Przedstawione w niniejszym artykule wyniki badań jednoznacznie wykazały celowość przeprowadzenia modernizacji laboratoryjnego przesiewacza WP. Modernizacja, która polegała na zmianie układu napędowego z wersji klasycznej na układ wyposażony w dwa silniki wibracyjne mocowane na ramie umieszczonej bezpośrednio na rzeszocie przesiewacza, przyniosła oczekiwane korzyści. Najważniejsze wymieniono poniżej:

- Podobnie jak w przypadku klasycznego układu napędowego uzyskano efekt samosynchronizacji wibratorów.

- Obniżono znacząco masę układu napędowego i gabaryty konstrukcji.

- Podniesiono bezpieczeństwo, likwidując występowanie elementów wirujących.

- Nowy napęd powinien zapewnić wydłużoną bezawaryjną eksploatację dzięki szczelnej obudowie łożysk wibratora.

- Charakter pracy urządzenia został zachowany - uzyskano liniowe trajektorie drgań.

- Zastosowanie nowego układu pozwoliło na uzyskanie mniejszej maksymalnej wartości amplitudy, ale jednocześnie pozwala na pracę z wyższą częstotliwością drgań, co finalnie umożliwia uzyskanie porównywalnych parametrów technologicznych przesiewacza. 
- Nowy układ napędowy pracuje stabilnie przy częstotliwości drgań powyżej 16,5 Hz; dalsze zwiększanie częstotliwości nie ma istotnego wpływu na wartość amplitudy z wyjątkiem punktów najbardziej oddalonych od napędu (3L i 3P), gdzie zauważono obniżenie jej wartości. Podobnie zachowywał się przesiewacz z klasycznym układem napędowym.

- Zastosowanie nowego układu umożliwia pracę przesiewacza w pełnym zakresie rekomendowanych wskaźników podrzutu (od 1,6 do 3,2) przy częstotliwości prądu zasilania silników od $40 \mathrm{~Hz}$ do $60 \mathrm{~Hz}$. Znamionowa częstotliwość pracy zastosowanych silników wibracyjnych wynosi $60 \mathrm{~Hz}$, co umożliwia ich ciąłą eksploatację przy takich nastawach.

Podsumowując, przeprowadzone badania wykazały zasadność modernizacji przemysłowych przesiewaczy wyposażonych w klasyczny układ napędowy. Modernizacja taka pozwala m.in. na podniesienie niezawodności pracy przy zachowaniu parametrów technologicznych urządzenia - niemniej jednak przed modernizacją wskazane jest przeprowadzenie pomiarów drgań starego układu w celu właściwego doboru silników wibracyjnych.

\section{Literatura}

Banaszewski T., 1990, Przesiewacze, Wydawnictwo „Śląsk”, Katowice.

Banaszewski T., Feliks J., Filipowicz A., Kalukiewicz A., 2007, Przesiewacze stosowane $w$ wytwórniach mas mineralno-bitumicznych, [w:] Nowoczesne metody eksploatacji wegla $i$ skat zwięzlych, University of Science and Technology AGH, Faculty of Mechanical Engineering and Robotics, Department of Mining, Dressing and Transporting Machines, Kraków, s. 223-229.

Będkowski B., 2019, Analiza konstrukcji modelowego elektrowibratora z magnesami trwałymi, Maszyny Elektryczne: zeszyty problemowe, nr 2(122), s. 71-78.

CARBOAUTOMATYKA, b.d., Przesiewacze wibracyjne, https://carbo.com.pl/kategoria/ przesiewacze-wibracyjne [dostęp: 24.06.2021].

Dietrych J., 1962, Teoria i budowa przesiewaczy, wyd. 2, Wydawnictwo Górniczo-Hutnicze, Katowice.

Feliks J., Filipowicz A., 2007, Sita dla wielopoktadowych przesiewaczy o drganiach prostoliniowych, [w:] Nowoczesne metody eksploatacji wegla i skat zwięztych, University of Science and Technology AGH, Faculty of Mechanical Engineering and Robotics, Department of Mining, Dressing and Transporting Machines, Kraków, s. 231-236.

Feliks J., Filipowicz A., 2008, Przesiewacze w wytwórniach mas mineralno-bitumicznych, Kopaliny, nr 1, s. 73-75. 
MIFAMA, b.d., http://mifama.com.pl/files/informations/ [dostęp: 24.06.2021].

Qnisz ING, b.d., https://qnisz.pl/ [dostęp: 6.07.2021].

Sidor J., Feliks J., Mazur M., Tomach P., 2015, Technika wibracyjna w przeróbce surowców mineralnych, [w:] Krauze K. (red.), Mechanizacja, automatyzacja i robotyzacja w górnictwie: praca zbiorowa: monografia, Centrum Badań i Dozoru Górnictwa Podziemnego Sp. z o.o. w Lędzinach, Katedra Maszyn Górniczych, Przeróbczych i Transportowych AGH w Krakowie, Lędziny - Kraków, s. 102-111.

Wodziński P., 1997, Przesiewanie i przesiewacze, Wydawnictwo Politechniki Łódzkiej, Łódź. 